УДК [159.922.7:159.923]:364.632

DOI: 10.37026/2520-6427-2021-105-1-60-63
Владислав ПАПУША, кандидат психологічних наук, доцент кафедри педагогіки, психології та корекиійної освіти Рівненського обласного інституту післядипломної педагогічної освіти, м. Рівне, Україна

ORCID: 0000-0002-7972-2465

e-mail:vladpp@i.ua

\title{
СУЧАСНЕ ТРАКТУВАННЯ ПРОБЛЕМ НАСИЛЬСТВА НАД ДИТИНОЮ
}

\begin{abstract}
Анотація. У статті проаналізовано основні документами, щзо регулюють питання захисту прав дитини на законодавчому рівні. Виокремлено найбільш характерні причини насильства над дітьми. Окреслено три групи чинників ризику, як-от: педагогічна та соиіальна занедбаність, відхилення в стані здоров'я дітей, віктимні особливості. Зазначено, щуо найбільш уразливою категорією щцодо насилля $\epsilon$ «важкі діти», зокрема підлітки. Схарактеризовано основні причини труднощів у вихованні дітей. Обгрунтовано, щзо насильство над дітьми може включати в себе будь-яку дію насильницьького характеру, нехтування, зловживання або нездатність, небажання чи невміння виховання і турботи за
\end{abstract}

дітьми від батьків чи інщих осіб, щуо призводить до фактичної або потенційної шкоди дитині. Визначено можливі наслідки насилля над дітьми. Доведено, щзо неправильне виховання в сім'ї може стати джерелом деформачії характеру дитини, а нерідко і вираженої патологіï, при иььму знання дорослими, зокрема батьками і педагогами, типів неправильного виховання та їхньої негативної дї на формування особистості дитини може мати важливе психологічне значення для корекиії умов сімейного виховання.

Ключові слова: особистість дитини, насильство, агресія, жертва насильства, віктимність, взаємостосунки.

\section{Vladyslav PAPUSHA,}

PhD in Psychology, Associate professor,

Department of Psychology

and Correctional Education,

Rivne Regional Institute

of Postgraduate Pedagogical Education,

Rivne, Ukraine

ORCID: 0000-0002-7972-2465

e-mail:vlad_p@i.ua

\section{MODERN INTERPRETATION OF THE PROBLEMS OF VIOLENCE AGAINST CHILDREN}

\begin{abstract}
Annotation. The article analyzes the problems of violence against children. The essence and content of the complex of influences of risk factors are revealed, among which, first of all, there are: pedagogical neglect; social neglect and abnormalities in the child's health. Victim features of adolescents are characterized. It has been argued that violence violates many of the rights of those protected by international human rights law. The government is responsible for taking measures to eliminate violence and provide equal protection for victims of violence. It is substantiated that the state should also take care of the development and proper functioning of social and psychological services, training of qualified psychologists and social educators, because their activities should bring the broadest and most effective results in solving the problem of domestic violence among Ukrainian families. Every child is guaranteed the right to liberty, security of person, protection of dignity and the best interests of the child.
\end{abstract}

It has been shown that child abuse can include any act of violence, neglect, abuse or inability, unwillingness or inability to raise and care for children from parents or others, leading to actual or potential harm to the child. This problem at the present stage is quite acute and requires research and practical action. It is emphasized that in the 21 st century, society must realize that violence against children is a problem of society as a whole. It is proposed to introduce the obligation of everyone to report the offenses committed against children that cause moral or material damage, damage to physical, mental health, moral development of the child. A timely response to reports of violence and other wrongdoing against children will undoubtedly contribute to preventive measures aimed at eliminating, blocking and neutralizing the determinants of their wrongdoing. At the same time, children themselves must be aware of their right to protection from all forms of violence. It is emphasized that in the 21st century, society must realize that violence against children is a problem of society as a whole. It is proposed to introduce the 
obligation of everyone to report the offenses committed against children that cause moral or material damage, damage to physical, mental health, moral development of the child.

Key words: child's personality, violence, aggression, victim of violence, victimhood, relationships.

Постановка проблеми. Одним із показників соціальної зрілості суспільства є ставлення до дітей, адже саме діти - майбутнє держави. В суспільстві, зорієнтованому на високі загальнолюдські цінності, не можуть бути терпимі прояви насильства над дітьми та жорстокого поводження $з$ ними.

Ще донедавна в нашому суспільстві вважалося неприйнятним говорити відверто про насильство над дітьми, зокрема і в сім'ї. Проте ця форма насильства існує давно і трапляється досить часто: вона розповсюджена серед людей різних національностей, різного фінансового та соціального статусу, в сім'ях віруючих та атеїстів. Більше того, таке насильство ніяк не можна пояснити економічною нестабільністю, оскільки воно наявне й у відсталих, і в економічно розвинутих країнах (Проблема насильства в сім’ї над дітьми стосується кожного, 2020).

Означена проблема небезпечна насамперед тим, що від неї страждають діти, а в майбутньому переносять цей негативний досвід у власне життя. Жорстоке поводження 3 дітьми і зневажання їхніми інтересами можуть мати різні види і форми, але їх наслідками завжди є серйозний збиток для здоров'я, розвитку і соціалізації дитини, нерідко й загроза ії життю чи навіть причиною смерті.

Аналіз наукових досліджень і публікацій. Проблемі насильства над дитиною присвячено чимало наукових розвідок. Так, серед основних напрямів дослідження означеного феномену варто виокремити такі: специфічні особливості у поведінці та риси характеру особистості дитини, що спричиняють насильство (О. Мойсеєва, Т. Сафонова, В. Туляков, В. Шахрай); класифікація та типологія відхилень у розвитку і поведінці підлітків (І. Кон, Н. Максимова, В. Татенко, Т. Титаренко та ін.); психологічна детермінація прояву віктимної поведінки (О. Андроннікова, М. Долгових, В. Мінська); форми та причини виникнення віктимної поведінки підлітків (І. Малкіна-Пих); віктимогенні внутрішньоособистісні конфлікти у підлітковому віці (Г. Ложкін, Л. Романова, С. Фоміних); віктимогенні норми, правила поведінки віктимної і протиправної субкультури (Л. Шабанов); віктимологічна ситуація, яка сприяє особистісній вразливості підлітка (Н. Волянюк, Т. Матанцева) та ін.

Крім того, це питання в Україні розглядається і на законодавчому рівні. Документами, які регулюють питання захисту прав дитини в Україні, є Конвенція про права дитини (1991); Конституція України, в статті 52 якої зокрема зазначається, що будь-яке насильство над дитиною та іiі експлуатація переслідуються за законом; Сімейний кодекс України (2004); Постанова Кабінету Міністрів України «Про порядок розгляду заяв та повідомлень про вчинення насильства в сім’ї або реальну його загрозу» (2003); Наказ Державного комітету України у справах сім’ї та молоді, Міністерства внутрішніх справ України, Міністерства освіти і науки України, Міністерства охорони здоров’я України «Про порядок розгляду звернень та повідомлень 3 приводу жорстокого поводження з дітьми або реальної загрози його вчинення» (2004); Закони України «Про нові сімейні норми» (1998), «Про покращення прав дитини» (2000), «Про право дитини на виховання без насильства» (2001), «Про попередження насильства в сім’ї» (2001) та «Про охорону дитинства» (2001), «Про ратифікацію Європейської конвенції про здійснення прав дітей» (2006) та ін.

Незважаючи на представлені вище джерела, означена проблема і надалі залишається надзвичайно актуальною та потребує подальшого вивчення й обгрунтування.

Мета статті - окреслити основні причини та можливі наслідки насильства над дитиною.

Виклад основного матеріалу дослідження. Насильство над дітьми або жорстоке поводження 3 ними - це фізичне, психологічне, сексуальне насильство або відсутність виховання та піклування над дітьми батьками або особами-опікунами.

До насильства завжди призводить комплекс чинників ризику, серед яких насамперед варто виокремити педагогічну занедбаність, соціальну занедбаність та відхилення в стані здоров'я дитини.

Неабияку роль у розповсюдженні жорстокості до дітей відіграє необізнаність батьків або осіб, що їх замінюють, про те, які заходи впливу неприпустимі стосовно відношення до дитини, нерозуміння, що не кожне покарання йде їй на користь. Не менш важливе значення має також низький рівень правової культури населення, недостатні знання законодавчих норм, що охороняють права дитини та гарантують покарання насильників.

Найчастіше насильство над дітьми проявляється в сім'ї. Найбільш розповсюдженими причинами жорстокого поводження 3 дітьми є: негативні моральні якості батьків, важке матеріальне становище сім’ї, конфлікти між батьками, асоціальний спосіб поведінки батьків, незадоволеність батьків власним соціальним станом, життевими невдачами. Жорстокість також може бути проявом психічного захворювання батьків чи інших кривдників.

Високий ризик стати жертвами насильства мають такі категорії дітей: небажані діти, а також ті, які були народжені після втрати батьками попередньої дитини; недоношені діти, які мають під час народження низьку вагу; діти, які живуть у багатодітній родині, де час між народженнями дітей був незначним; діти iз вродженими або набутими захворюваннями, каліцтвами, низьким інтелектом, порушеннями здоров'я (спадковий синдром, хронічні захворювання, зокрема й психічні); діти з розладами й особливостями поведінки (дратівливі, імпульсні, гіперактивні, з непередбачуваною поведінкою, порушеннями сну та енурезом); діти з певними властивостями особистості (вимогливі, замкнуті, апатичні, байдужі); діти з негативними звичками та низькими соціальними навичками; діти з особливостями зовнішності, що відрізняються від інших або важко «переживаються» батьками, з якими вони ніяк не можуть примиритися (наприклад, «не тієї» статі); діти, які часто хворіли і були розлучені з матір'ю впродовж першого року життя (Сушик, 2014, ).

Діти, які зазнали приниження і наруги, як правило, стають носіями агресії, сповідують культ сили. Найбільш типовими наслідками такої ситуації стають скарги батьків чи вчителів на поведінку дітей, як-от: 
бійки, конфлікти з оточуючими, низька успішність, замкненість тощо. При цьому діти, які зазнають жорстокого поводження і насильства, за психологічною допомогою звертаються вкрай рідко.

Агресивна поведінка дитини, її важкий характер, особливі потреби (наприклад, годування хворої дитини, схильність до рутинного порядку при аутизмі, неуважність, незручність і надмірна рухливість) сприяють збільшенню в родині дистресу, а як наслідок вірогідності прояву насильства до дитини. Часто саме «важкі» діти стають жертвами насильства як у школі, так і вдома, а ще входять до числа осіб із віктимністю - підвищеною здатністю людини через низку духовних і фізичних властивостей, соціальну роль чи статус за певних обставин ставати жертвою злочину (Мойсеєва, 2000, C. 99-100).

На підставі аналізу сучасної психолого-педагогічної літератури можна виокремити три істотних ознаки поняття «важкі діти»: по-перше, наявність у дітей або підлітків поведінки, що відхиляється від норми; nо-друге, порушення у поведінці, яку складно виправити або скоректувати; no-третє, необхідність індивідуального підходу з боку вихователів, а також уваги з боку колективу однолітків.

Найбільш уразливою категорією є підлітки, адже, як відомо, підлітковий період - час перебудови організму, коли відбувається бурхливий і нерівномірний ріст, що супроводжується невідповідністю, нерівномірністю в розвитку серцевого м'яза і судин. Посилена діяльність залоз внутрішньої секреції призводить до тимчасових розладів кровообігу, підвищення артеріального тиску, напруження серцевої діяльності, підвищення збудження. Усі ці фактори сприяють підвищенню дратівливості, швидкій стомлюваності, запамороченню, прискореному серцебиттю.

Віктимні властивості, характерні для підлітків, поділяють на дві групи - загальні та індивідуальні. До загальних належать: довірливість, допитливість, наївність, невміння адекватно реагувати на ситуацію, відставання психічного розвитку від фізичного, фізична слабкість тощо. Індивідуальні віктимні властивості поділяють на фактори, серед яких:

- біопсихологічні-тип темпераменту, наявність рис, характерних для одного з патопсихологічних симптомокомплексів (шизофренічний, психопатичний тощо);

- nсихологічні - агресивність, тривожність, жорстокість, необ'єктивна оцінка можливостей, емоцій, неврівноваженість або наявність однієї чи декількох акцентуацій характеру;

- соціально-психологічні - потреба в спілкуванні, самоствердження, правова необізнаність, незнання головних методів забезпечення особистої безпеки тощо (Сидоренко, 2001, с. 37).

На формування зростаючої особистості та іï подальшої долі неабияке значення відіграє педагогічна занедбаність, під якою розуміють «стійкі відхилення від норми в моральній свідомості й поведінці чи навчальній діяльності, спричинені недоліками педагогічного впливу» (Український педагогічний словник, 1997).

В основу педагогічної занедбаності покладено три групи чинників, що іії обумовлюють: недоліки в освітньо-практичних і соціально-етичних знаннях, наявність спотворених понять і негативного життєвого досвіду; відхилення від норми або дефекти в розвитку рис і якостей особистості; недоліки або відхилення від норми у взаємовідносинах із іншими. Як наслідок - порушуються зв'язки особистості із середовищем, відносини 3 оточуючими набувають конфліктного характеру, поведінка починає все більш відхилятися від загальноприйнятих норм. Педагогічна занедбаність може спостерігатися в будь-якому віці дитини, і в кожному вона має свої особливості, однак найяскравіше вікова специфіка педагогічної занедбаності виявляється саме в підлітків.

Серед основних причин труднощів у вихованні окремих школярів варто виокремити: конфліктні відносини в сім’ї; прорахунки виховної системи школи; ізоляція від товаришів; соціальна дезадаптація; прагнення ствердити себе будь-яким способом і в будь-якій групі. Однак найчастіше окреслені вище причини наявні в комплексі. Подібна ситуація призводить до небажаних змін у свідомості та поведінці учня.

У зв'язку з цим варто наголосити, що батьки не завжди своєчасно реагують на появу недоліків у характері своїх дітей: неврівноваженість, підвищену збудливість, образливість або повну байдужість. Деякі 3 них пояснюють примхливість, недисциплінованість, нестриманість своїх дітей нервовістю та хворобливістю. Це сприяє появі у батьків відчуття невдоволеності своїми дітьми, що нерідко і спричиняє насилля в родині (Сафонова, 2007, с.18).

Які ж суспільні втрати від насильства над дітьми? Це насамперед втрати людського життя в результаті вбивств дітей і підлітків, їхніх самогубств, принесення шкоди їхньому здоров'ю, як психічному, так і фізичному, низький освітній і професійний рівень, кримінальна поведінка та ін. Так, зі 100 випадків фізичного насильства над дітьми приблизно 1-2 закінчуються смертю жертви насильства. Наслідками фізичного насильства є синці, травми, переломи, ушкодження внутрішніх органів: печінки, селезінки, нирок та ін. Потрібен час, щоб залікувати ці ушкодження, але ще більше часу і зусиль потрібно для того, щоб залікувати сердечні рані, психіку дитини, що постраждала від насильства.

Незалежно від виду і характеру насильства в дітей можуть спостерігатися різні захворювання, що належать до психосоматичних: ожиріння чи, навпаки, різка втрата ваги, що обумовлено порушеннями апетиту. Під час емоційного (психічного) насильства нерідко бувають шкірні висипання, алергійна патологія, виразка шлунку тощо. Часто в дітей спостерігаються такі нервово-психічні захворювання, як тики, заїкання, енурез (нетримання сечі), енкопрез (нетримання калу), деякі діти потрапляють у відділення невідкладної допомоги 3 травмами та отруєннями.

Діти, які пережили будь-який вид насильства, відчувають труднощі соціалізації: у них порушені зв'язки з дорослими, відсутні відповідні навички спілкування 3 однолітками, вони не мають достатнього рівня знань і ерудиції, щоб завоювати авторитет у школі тощо. Вирішення своїх проблем діти-жертви насильства часто знаходять у кримінальному, асоціальному середовищі, що згодом спонукає до появи у них пристрасті до алкоголю, наркотиків здійсненню інших протиправних дій (Виховання без насильства, 2020).

Отже, будь-який вид насильства формує в дітей і підлітків такі особистісні й поведінкові особливості, які роблять їх малопривабливими і навіть небезпечними для суспільства. 
Діти - не вроджені анархісти, їм не потрібна безмежна свобода, як вважають деякі дорослі. Навпаки, щоб відчувати себе захищеними, дітям необхідні рамки та межі дозволеного. Тому вони з готовністю підкоряються суспільним правилам та законам і бурхливо протестують проти необгрунтованих проявів насильства 3 боку люблячих дорослих. Імовірно, їхній незахаращеній буттям свідомості відкрито більше, ніж розуму дорослих: повага до особистості й насильство над нею - речі несумісні.

Висновки. Неправильне виховання в сім’ї може стати джерелом деформації характеру дитини, а нерідко і вираженої патології. Знання дорослими, зокрема батьками і педагогами, типів неправильного виховання та їхньої негативної дії на формування особистості дитини може мати важливе психологічне значення для корекції умов сімейного виховання.

Правильне виховання в сім'ї має поєднувати заохочення, примушування і покарання. Дитина потребує послідовного та виваженого контролю поведінки. Не слід перебільшувати вимоги до неї, перенавантажувати обов' язками, особливо насильно нав' язувати такі форми діяльності, до яких у дитини немає ні інтересу, ні схильностей. Не рекомендується використовувати такі виховні засоби, як постійні зауваження, заборони, погрози, залякування, покарання, тим більше - фізичні. Однак не слід і поступатися необгрунтованим вимогам і примхам дитини, створювати навколо неї «тепличну атмосферу», захоплюватися іiї поведінкою, надмірно хвалити та захищати від життєвих труднощів і конфліктів.

Насамкінець хочемо зауважити, що саме сім'я має стати для кожної дитини місцем безпеки, затишку та комфорту в нашому такому бурхливому світі, місцем, де іiі розумітимуть і поважатимуть, де вона нікого не боятиметься і завжди почуватиметься в безпеці.

Подальші наші дослідження плануємо присвятити впровадженню в освітній процес Обласної програми «Створення безпечного освітнього середовища».

\section{СПИСОК ВИКОРИСТАНОЇ ЛІТЕРАТУРИ}

Проблема насильства в сім'ї над дітьми стосується кожного (2020). URL: https://shostka-rada.gov. ua/problema-nasylstva-v-sim-yi-nad-ditmy-stosuyetsyakozhnogo/ (дата звернення: 15.09.2020).

Про охорону дитинства: Закон України від 26.04.2001 p. № 2402. Офіиійний вісник Украӥни. 2001. № 22. C. $15-21$.

Про попередження насильства в сім’і: Закон України від 15.11.2001 р. № 2789-III (зі змінами та доповненнями). Офіиіийний вісник України. 2001. № 51. С. 41. $187 \mathrm{c}$.

Конвенція про права дитини. (2001). Київ: ІЗМН.

Конституція України від 28.06.1996 p. № 254к/96-BP (зі змінами та доповненнями). URL: https://zakon.rada.gov.ua/laws/show/254\%D0\%BA/96$\% \mathrm{D} 0 \% \mathrm{~B} 2 \% \mathrm{D} 1 \% 80 \#$ Text (дата звернення: 05.10.2020).

Сушик, Н. (2014). Сутність, види, фактори виникнення насильства над дітьми в сім'і. Дитинство без насилля: суспільство, школа і сім'я на захисті прав дітей: матеріали Міжнародної науково-практичної конференції (м. Тернопіль, 29-30 квітня 2014 р.). Тернопіль. URL: https://evnuir.vnu.edu.ua/ bitstream/123456789/4384/1/violenc.pdf (дата звернення: 15.09.2020).
Мойсеєва, О. (2000). Віктимність неповнолітніх як психолого-правова проблема. Право України. №7. С. 99-100.

Сидоренко, О. (2001). Правові та психологічні аспекти вирішення конфліктів, пов'язаних з насильством у сім’ях. Право Украӥни. № 6. С. 37-41.

Український педагогічний словник (1997) / упоряд. С. Гончаренко. Київ: Либідь. 376 с.

Сафонова, Т. Я. (2007). Жестокое обращение с детьми. Практична психологія та соиіальна робота. № 2. C. 17-29.

Виховання без насильства (2020). URL: https:// rotmistrivska-gromada.gov.ua/news/1582191209/ (дата звернення: 17.09.2020).

\section{REFERENCES}

Problema nasylstva v simi nad ditmy stosuietsia kozhnoho [The problem of domestic violence against children]. (2020). URL: https://shostka-rada.gov.ua/problema-nasylstva-v-sim-yi-nad-ditmy-stosuyetsya-kozhnogo/ (data zvernennia: 15.09.2020). [in Ukrainian].

Zakon Ukrainy «Pro okhoronu dytynstva» vid 26.04.2001 p. kvitnia 2001 r. № 2402 [Law of Ukraine «On Child Protection»]. Ofitsiinyi visnyk Ukrainy. 2001. 22. S. 15-21. [in Ukrainian].

Pro poperedzhennia v simi:Zakon Ukrainy vid 15.11.2001 r. № 2789-III [Law of Ukraine «On Prevention of Domestic Violence»]. Ofitsiinyi visnyk Ukrainy. № 51. S. 41. [in Ukrainian].

Konventsiia pro prava dytyny[Convention on the Rights of the Child]. (2001). Kyiv: IZMN. 187 s. [in Ukrainian].

Konstytutsiia Ukrainy vid 28.06.1996 r. № 254k/96-VR [Constitution of Ukraine]. URL: https://zakon.rada.gov. ua/laws/show $/ 254 \%$ D0\%BA/96-\%D0\%B2\%D1\%80\#Text (data zvernennia: 05.10.2020). [in Ukrainian].

Sushyk, N. (2014). Sutnist, vydy, faktory vynyknennia nasylstva nad ditmy $\mathrm{v}$ simyi [Essence, types, factors of violence against children in the family]. Dytynstvo bez nasyllia: suspilstvo, shkola i simia na zakhysti prav ditei: materialy Mizhnarodnoi naukovo-praktychnoi konferentsii (Ternopil, 29-30 kvitnia 2014 r.). URL: https://evnuir. vnu.edu.ua/bitstream/123456789/4384/1/violenc.pdf (data zvernennia: 15.09.2020). [in Ukrainian].

Moiseieva, O. (2000). Viktymnist nepovnolitnikh yak psykholoho-pravova problema [Victimisation of minors as a psychological and legal problem]. Pravo Ukrainy. № 7. S. 99-100. [in Ukrainian].

Sydorenko, O. (2001). Pravovi ta psykholohichni aspekty vyrishennia konfliktiv, poviazanykh z nasylstvom u simiakh [Legal and psychological aspects of resolving conflicts related to domestic violence]. Pravo Ukrainy. № 6. S. 37-41. [in Ukrainian].

Ukrainskyi pedahohichnyi slovnyk [Ukrainian pedagogical vocabulary] (1997) / uporiad. S. Honcharenko. Kyiv: Lybid. 376 s. [in Ukrainian].

Safonova, T. Ya. (2007). Zhestokoe obrashchenye s detmy [Child abuse]. Praktychna psykholohiia ta sotsialna robota. № 2. S. 17-29. [in Russian].

Vykhovannia bez nasylstva [Upbringing without violence] (2020). URL: https://rotmistrivska-gromada. gov.ua/news/1582191209/ (data zvernennia: 17.09.2020). [in Ukrainian].

Дата надходження до редакиіï: 23.11.2020 p. 